\title{
Social Skills of Pupils with Mild Intellectual Disability: Do Peer Tutoring, Storytelling and Gender Play a Role?
}

\author{
Udeme Samuel Jacob ${ }^{1,2, *}$, Jace Pillay ${ }^{1}$, Olajumoke Christiana Ayandokun ${ }^{2}$, John Olusegun Oyundoyin ${ }^{2}$ \\ ${ }^{\mathbf{1}}$ Faculty of Education, University of Johannesburg, South Africa \\ ${ }^{2}$ Department of Special Education, Faculty of Education, University of Ibadan, Oyo state, Nigeria
}

Received June 15, 2021; Revised August 3, 2021; Accepted August 22, 2021

\begin{abstract}
Cite This Paper in the following Citation Styles
(a): Udeme Samuel Jacob, Jace Pillay, Jumoke Ayandokun, John Olusegun Oyundoyin, "Social Skills of Pupils with Mild Intellectual Disability: Do Peer Tutoring, Storytelling and Gender Play a Role?," Universal Journal of Educational Research, Vol. 9, No. 12, pp. 1887 - 1897, 2021. DOI: 10.13189/ujer.2021.091201.
\end{abstract}

(b): Udeme Samuel Jacob, Jace Pillay, Jumoke Ayandokun, John Olusegun Oyundoyin (2021). Social Skills of Pupils with Mild Intellectual Disability: Do Peer Tutoring, Storytelling and Gender Play a Role? Universal Journal of Educational Research, 9(12), 1887 - 1897. DOI: 10.13189/ujer.2021.091201.

Copyright $\bigcirc 2021$ by authors, all rights reserved. Authors agree that this article remains permanently open access under the terms of the Creative Commons Attribution License 4.0 International License

\begin{abstract}
Background: This research examined the significant main effect of peer tutoring, storytelling, and gender, on the social skills of pupils with mild intellectual disability. Using the Social Development Theory of Lev Vygotsky as the rationale for this study, the acquisition of social skills is viewed as based on a social constructivist view of learning. Methodology: The study sample consisted of thirty-four pupils with intellectual disability, purposively selected from three schools in Ibadan Metropolis, and randomly assigned to one of the peer tutoring, storytelling, or control groups. Thirty sessions were held over ten weeks with the peer tutoring and storytelling experimental groups only. A social skills performance scale was administered before and after the intervention to collect data from these three groups. An analysis of covariance was used to examine the data collected. Results: Findings based on the analysed data revealed that there was a significant statistical difference between pre-test and post-test results of the three groups. The effect of gender on social skills of participants was significant, as was the interaction effect of treatment and gender. Conclusion: Recommendations based on the finding of this study are that peer tutoring and storytelling be adopted for teaching social skills to pupils with mild intellectual disability, and that pictorial illustration be used to enhance their reading skills.
\end{abstract}

Keywords Mild Intellectual Disability, Peer Tutoring, Social Development Theory, Social Skills, Storytelling

\section{Introduction}

Difficulty in socialising or sustaining relationships is a major characteristic of persons with mild intellectual disability that negatively affects their academic ability. Learners who have appropriate social skills understand both written and implied rules when interacting with others and know how to act in a variety of social situations. Individuals with good social skills find it easier to express their satisfaction or dissatisfaction, protect their individual rights, seek assistance from others when necessary, and reject unfavourable expectations [1]. It can be inferred that social skills are necessary for comprehending and analyzing information in a sociocultural environment [2].

The development of individuals, including those categorised as intellectually disabled, largely depends on the company they keep. The power of influence in developing appropriate social skills required for effective interaction cannot be overemphasized. This is because humans are products of ideas, beliefs, and thought patterns acquired from various sources and experiences. An individual's ability to interact effectively with others in a specific social context is known as social skills.

Social skills include our ability to communicate and interact with each other, both verbally and non-verbally, through gestures, body language, and our personal appearance. Some individuals, however, have problems learning appropriate behaviours [3], because they lack the necessary social skills, such people are unable to interact 
effectively with those around them [4]. The lack of social skills gives rise to challenges which may lead to depression, social anxiety, solitude, and alcoholism later in life [5].

In pupils with mild intellectual disability, poor social skills stem primarily from the fear of being different and of being made the object of jest, bullying, and, in the worst cases, rejection. Social skills underlie good relations between people [6]. Pupils with intellectual disability do not usually possess social skills commensurate with their chronological age. The resulting effect is the exhibition of poor communication skills, lack of empathy, and poor problem-solving abilities. Moreover, poor social skills will lead to poor communication skills and subsequent rejection by their peers [7].

Academic achievement, general quality of life, conformance, psychological health, and social achievement all necessitate the development of social skills [8]. It should be noted that any social skills training that resolves social relationship challenges will improve overall quality of life and happiness [9]. Language pragmatics, which includes both verbal and nonverbal abilities that enable communication flow as well as critical tools for understanding and analyzing messages within a socio-cultural environment, is required for social skills [2].

For pupils to exhibit appropriate social skills, there must be a level of interest in learning such skills. Learning may occur through observation of family members, other adults, and peers as models. This is an unconscious and nonsystematic learning method which is usually not valid for pupils with intellectual disability. In other words, a pupil with intellectual disability cannot learn social skills in the same way as a regular learner without any form of disability. That is why systematical training and support is necessary for pupils with intellectual disability to acquire social skills.

This vital training helps them attain self-reliance, independence, and maximum academic excellence. It also helps individuals with intellectual disability understand and know their civic rights and responsibilities so that they are not trampled upon. It exposes them to the acceptable norms of society, so that they do not act irresponsibly in public. To this end, this study seeks to investigate the effect of peer tutoring, storytelling, and gender, on social skills among pupils with intellectual disability while the moderating variable is gender.

\section{Hypothesis}

The following hypotheses were formulated:

$\mathrm{H}_{1}$ : There is no significant main effect of treatment in enhancing the social skills of pupils with mild intellectual disability.

$\mathrm{H}_{2}$ : There is no significant main effect of gender on social skills of pupils with mild intellectual disability.

$\mathrm{H}_{3}$ : There is no two-way interaction of treatment and gender on the social skills of pupils with mild intellectual disability.

The $\mathrm{H}_{0}$ will be accepted if there is a statistically significant difference in each of the above hypotheses.

\section{Literature Review}

\section{Social Development Theory of Lev Vygotsky}

The concept of learning through peer tutoring and storytelling is based on a social constructivist view that highlights the importance of learning from peer mentorship through socialisation in proximal development areas [10].Users actively participate in making meaning in stimulus-response processes through cognitive integrating activities. [11].

Learning according to Vygotsky [10], occurs through social negotiating process within a cultural environment, with language serving as the primary enabling tool. $\mathrm{He}$ theorised that knowledge was co-constructed and that individuals learn from one another. This theory is known as social constructivist theory because, in the opinion of Vygotsky, students must participate actively in the learning process. With the support of other individuals, learning takes place, thereby contributing to the social element of the theory. The social constructivist or social development theory has recently been expanded to include a framework of cognitive learning [12] through which students learn in a way comparable to conventional learning.

Learners gain access to professional information through role models, who facilitate rather than teach, with the goal of learning to solve realistic and practical challenges in real-world situations. Just as in conventional apprenticeships, learners take part in on-the-job tasks rather than being taught abstract concepts in a didactic way. The central idea of Vygotsky's theoretical framework is that social interaction is critical to the development of cognitive processes. According to Vygotsky [10], every feature in the child's cultural development appears twice: once on the social level and once on the individual level; once between people (interpsychological) and once within the child (intra-psychological). This holds true for voluntary attention, rational memory, and cognitive development. All higher functions emerge from genuine interpersonal relationships.

\section{Peer Tutoring and Social Skills}

According to researchers, peer tutoring impacts positively on student learning, motivation and socialization [13, 14]. Peer tutoring has been shown to play an important role in the development of creativity and problem-solving skills by both teachers and students. Because peer tutoring is interactive, the teacher can first understand the learners' mental level, their concept of the topic, and the best approach to present the knowledge to 
them. According to Gebes [15], anger was effectively managed among high school students using a peer tutoring approach. Tutors and tutees actively participated in collaborative work and meaningful tasks as part of a planned and structured program, which resulted in successful outcomes [16].

Moreover, Yelpaze [17] reported that a peer-mediated social skills training programme reduced aggressive behaviour in high school students. Another study discovered that peer tutoring helped children with social and emotional disorders improve their academic performance [18]. Furthermore, peer tutoring can benefit students by facilitating discussion, which leads to learning in a supportive environment. In the same vein, peer tutoring boosts introverted or shy students' confidence and cognitive levels [19], which may help them express themselves in front of the class [20] or other gatherings. Peer tutoring is also beneficial for institutions that provide inclusive educational services to pupils with special needs [21], as it has been demonstrated to substantially reduce social and behavioral problems among learners [22].

In this regard, tutors' ability to accept responsibility and gain a sense of control improved significantly [23]. As a method of teaching, peer tutoring helps to develop the skills of pupils, gives them self-confidence, and supports them while solving the problems they face [24]. Peer tutoring has been studied for its impact on success, attitudes, and retention, and the findings indicate that it is an effective teaching method, especially for students with learning disabilities [25, 26, 27].

\section{Storytelling and Social Skills}

Storytelling as a teaching method was initially developed to help individuals with autism spectrum disorders (ASD) acquire social skills [28, 29]. Later studies showed that storytelling could be used effectively in teaching safety skills, as well as social skills $[30,31$, 32], for individuals with learning disabilities [33], behavioural problems [34], and intellectual disabilities [35]. In a study which examined the effectiveness of social stories on teaching safety skills, Süzer [32] aimed to teach three participants with ASD, aged between 10 and 17, the skill of protecting themselves from sexual harassment. He observed that social stories were influential not only in the acquisition of the target skills, but in retaining them, and with the capacity for generalisation about different people and forms of harassment.

In another study, Kutlu [31] examined whether the delivery of social stories alone, and in combination with video modeling, differed in terms of effectiveness and efficiency in teaching four participants, aged between 10 and 13 with ASD, skills to protect them from strangers knocking on the doors and abduction attempts. Research results showed that three of the four participants learned the skills of protecting themselves from strangers at a level that met the criteria with both forms of implementation. The method of instruction using only social stories was more effective for the fourth participant.

Studies have shown that the instructions delivered by peers were effective in the acquisition of various target skills by individuals with developmental disabilities [36, 37]. In these studies, peers acquired the knowledge and skills to implement the simultaneous prompting procedure $[38,39]$, the constant time delay procedure $[40,41]$ and embedded instruction using the constant time delay procedure [42]. It was observed that after the instruction delivered by peers, individuals with developmental disabilities acquired the target academic skills [39, 42], daily life skills [40], leisure time skills [38], and social interaction and communication skills $[43,44]$.

\section{Gender and Social Skills}

Gender differences in the development of social skills in relationships and problem behaviors, according to research, begin at a young age. Boys were more likely than girls to engage in problem behaviors, but girls were more likely to have superior social and academic skills $[45,46,47,48,49,50]$. Clearly, more study is required to better understand gender differences in social skills. Furthermore, children's social skill may be profoundly influenced by their environment and cultural differences. According to the findings, different cultures place different emphasis on communication and socialization skills, as well as different expectations for acceptable and problematic behavior patterns [51]. This topic has not, however, been investigated extensively by professionals in non-western countries. Investigating social skills across cultures could help to develop a professional community-wide definition of the concept of social skills.

Males have lower verbal abilities and use less tentative, more assertive language than females, according to studies $[52,53,54]$. Furthermore, females outperform males in terms of emotion regulation and reading, as well as social group function [55, 56, 57]. Gender differences in language and socioemotional abilities appear to exist before birth. Neonatal males, for example, make fewer basic oral rhythmic and lingual movements while sucking [58]. Neonatal females, on the other hand, respond to sweetened formula with a reflex smile and have higher auditory sensitivity $[59,60]$. Other differences over the next few months include pain sensitivity, responsiveness to maternal vocalizations, and emotional expression discrimination [61, 62].

\section{Methodology}

\section{Research Design}

The study adopted the pretest-posttest and control group quasi-experimental research design with a $3 \times 2$ 
factorial matrix. There were two main experimental groups and one control group. The experimental group was exposed to treatments (peer tutoring and storytelling) while the no treatments were administered to the control group. The moderating variable was gender (male or female).

Experimental group 1: $\left(\mathrm{E}_{1}\right): \mathrm{O}_{1} \quad \mathrm{X}_{1} \quad \mathrm{O}_{4}$

Experimental group 2: $\left(\mathrm{E}_{2}\right): \mathrm{O}_{2} \quad \mathrm{X}_{2} \quad \mathrm{O}_{5}$

$\begin{array}{lll}\text { Control group 3: } & \text { (C): } \mathrm{O}_{3} & \mathrm{O}_{6}\end{array}$

$\mathrm{E}_{1}$ represents peer tutoring

$\mathrm{E}_{2}$ represents storytelling

Where $\mathrm{O}_{1}, \mathrm{O}_{2}$, and $\mathrm{O}_{3}$ represents pretest scores, $\mathrm{O}_{4}, \mathrm{O}_{5}$, $\mathrm{O}_{6}$ represents post test scores.

$\mathrm{X}_{1}$ represents the treatment package for experimental group1 (peer tutoring).

$\mathrm{X}_{2}$ represents the treatment package for experimental group2 (storytelling).

C for control group.

\section{Participants}

The study population were pupils with mild intellectual disability in Ibadan. Participants consisted of 34 pupils with intellectual disability, purposefully selected from 3 primary schools, identified as school $\mathrm{P}, \mathrm{S}$ and $\mathrm{C}$, in Ibadan, Oyo State. The small sample size was due to the unique characteristics of participants screened using the Slosson Intelligence Test to identify pupils with mild intellectual disability. In school $\mathrm{P}$, out of a population of 25 pupils $(\mathrm{N}=10$, male $=5$; female $=5$; mean age $=11.4), 10$ were classified as having mild intellectual disability. Out of 21 pupils $(\mathrm{N}=11$, male $=6$; female $=5$; mean age $=12.1)$ in school S, 11 had mild intellectual disability. In school C, out of 36 pupils $(\mathrm{N}=13$, male $=5$; female $=8$; mean age $=$ 11.7) 13 had mild intellectual disability. Consent was obtained in writing from each parent of the pupils selected for the study. Schools were assigned to a treatment group by ballot. Participants from school P were exposed to peer tutoring, those in school $\mathrm{S}$ were exposed to storytelling, while participants in school $\mathrm{C}$, the control group, were not exposed to any treatment. All the activities related to the study were conducted at the three schools from which participants were selected.

\section{Criteria for Inclusion}

1. The pupil must have spent two years in a schooling system.

2. The pupil had to be willing to participate in the study.

\section{Instrument}

The instruments consisted of the following: the Slosson Intelligence test, a peer tutoring treatment package, a storytelling treatment package, and a social skills performance scale. These are discussed below.

\section{Slosson Intelligence Test, Revised Third Edition}

The revised Slosson Intelligence Test (SIT-R3) is a quick and reliable individual screening test of crystallised verbal intelligence. The SIT-R3 is a multidimensional appraisal scale that can be used to assess both regular education and the majority special populations. Teachers, psychologists, guidance counselors, special educators, learning disability instructors, and others can use it to assess an individual's mental ability. The SIT-R3 tests vocabulary, quantitative skills, general information, comprehension, and auditory memory, many of which have been acquired through incidental learning. This test has been adapted to suit African cultures. Over time, validity coefficients have been calculated separately for each age level and the range was from 0.90 to 0.98 . The reliability coefficient (KR-20) by age levels, yielded values ranging from 0.88 to 0.97 . The reliability coefficient of this instrument was also determined by Oyefeso [63] as 0.91. The SIT-R3 now has adapted score sheets for scannable electronic readers and embossed materials allow testing of the visually impaired and the blind.

\section{Peer Tutoring Package}

As a teaching method to help improve the social skills of pupils with mild intellectual disability, peer tutoring was selected by the researchers and adapted to suit the special needs of participants. A step-by-step guide was followed when implementing the treatment package for experimental group 1 (peer tutoring). Pupils were paired so they could be each other's helpmate. Both parties are simultaneously helped to get better on existing skills. If, for instance, pupil A had difficulty in toileting, their helpmate - pupil B - assists them to achieve that skill. In this way, pupil A learns how to use the restroom by themselves, while pupil B learns how to put things in order themselves without an elder.

\section{Storytelling Package}

Storytelling was also selected by the researchers as a teaching method. The stories used were culled from the Pinwheel series, Social Habits for Pre-primary: Course Book 2. This guides the process of telling a story that extols the healthy social skills of lavishly illustrated characters. The story should be told with attention to tone to signify mood, accompanied by gestures and dramatisation. This process was followed when implementing the treatment package for experimental group 2 (storytelling) over a period of 6 weeks, 3 times per week. This helped stimulate interest looks that pupils looked forward to seeing what social skills would be covered next. It also helped sustain the attention span of the pupils for slightly longer periods. 


\section{Social Skills Performance Scale}

This package was developed by Gajewski, Hirn and Mayo [64] and adapted by the researchers to suit the educational needs and social requirement of each pupil with mild intellectual disability. The scale consisted of 20 items, with levels of involvement for each item labelled 1 to 5, with level 1 as the lowest (child never practices such skill) and level 5 as the highest (child always practices such skill). Where the level of involvement was low, these areas needed more attention from the teacher. The social skills scale was filled by the class teacher of the pupils in the pretest, and by the researcher during the posttest after completion of the treatment package (storytelling and peer tutoring). It was completed based on the observation of the pupil's social behaviour exhibited during the teaching and learning process in the classroom. The instrument was pilot tested to determine the reliability and it yielded a reliability coefficient of 0.74 . The reliability coefficient was obtained after analysis of the pilot testing to test the reliability and validity of the scale.

\section{Procedure for Data Collection}

The participating schools were presented with a letter of introduction from the researcher for approval after which participants were informed of the purpose of the study. A pretest exercise was carried out prior to the commencement of the treatment package. The treatment lasted for 10 weeks, with 3 weekly sessions of 50 minutes each. At the end of the 10 weeks, a posttest exercise was conducted to measure the effectiveness of the programme on the social skills of participants.

\section{Method of Data Analysis}

The data collected from this study was analysed using analysis of covariance (ANCOVA) on the SPSS version 23 to test the hypotheses at the 0.05 level of significance. ANCOVA was used based on its ability to reduce the effect of extraneous variables in the pretest and posttest measures. The direction of significant was determined using estimated.

\section{Results}

\section{Testing of Hypotheses}

This section presents the result of the tested hypotheses.

$\mathbf{H}_{1}$ : There will be no significant main effect of treatment on social skills of pupils with mild intellectual disability in Ibadan, Oyo State.

The results presented in Table 1 show a significant main effect of treatment on social skills of pupils with mild intellectual disability in Ibadan, Oyo State $\left(\underline{F}_{(2,28)}\right.$, $\left.147.589, p<.05, \eta^{2}=.799\right)$. This implies that the treatments contributed significantly to the variation in participants' scores. The eta-squared value of .799 shows that the treatments contributed about $80 \%$ to social skills of the participants. Therefore, the null hypothesis was not accepted.

Table 1. Summary of ANCOVA showing the pretest -posttest effects of treatment and gender on social skills of pupils with mild intellectual disability in Ibadan, Oyo State

\begin{tabular}{|c|c|c|c|c|c|c|}
\hline Source & $\begin{array}{c}\text { Type III Sum of } \\
\text { Squares }\end{array}$ & Df & Mean Square & F & Sig. & Partial Eta Squared \\
\hline Corrected Model & $893.517 \mathrm{a}$ & 5 & 178.703 & 19.907 & .000 & .806 \\
\hline Intercept & 9996.000 & 1 & 9996.000 & 1113.502 & .000 & .979 \\
\hline Treatment & 854.428 & 2 & 427.214 & 147.589 & .000 & .799 \\
\hline Gender & 121.712 & 1 & 121.712 & 45.191 & .023 & .218 \\
\hline Treatment* Gender & 442.428 & 2 & $221 . .214$ & 49.135 & .014 & .311 \\
\hline Error & 215.450 & 24 & 8.977 & & & \\
\hline Total & 17489.000 & 30 & & & & \\
\hline Corrected Total & 1108.967 & 29 & & & & \\
\hline
\end{tabular}


Table 2. Adjusted marginal mean showing the direction of difference in social skills between the treatment and control groups

\begin{tabular}{|c|c|c|c|c|}
\hline \multirow{2}{*}{ Treatment } & \multirow{2}{*}{ Mean } & \multirow{2}{*}{ Std. Error } & \multicolumn{2}{|c|}{ 95\% Confidence Interval } \\
\cline { 3 - 5 } & & & Lower Bound & Upper Bound \\
\hline Storytelling & 29.375 & .967 & 27.379 & 31.371 \\
\hline Peer tutoring & 23.833 & 1.579 & 20.574 & 27.092 \\
\hline Control & 16.200 & .947 & 14.245 & 18.155 \\
\hline
\end{tabular}

Table 3. Adjusted marginal mean showing the direction of difference in social skills between gender groups

\begin{tabular}{|c|c|c|c|c|}
\hline \multirow{2}{*}{ Sex } & \multirow{2}{*}{ Mean } & \multirow{2}{*}{ Std. Error } & \multicolumn{2}{|c|}{ 95\% Confidence Interval } \\
\cline { 3 - 5 } & & & Lower Bound & Upper Bound \\
\hline Male & 22.833 & 1.168 & 20.424 & 25.243 \\
\hline Female & 23.439 & .748 & 21.895 & 24.983 \\
\hline
\end{tabular}

Table 4. Adjusted marginal mean showing the direction of difference in social skills of pupils with intellectual disability by interaction of treatment and gender

\begin{tabular}{|c|c|c|c|c|c|}
\hline \multirow{2}{*}{ Treatment } & \multirow{2}{*}{ Gender } & \multirow{2}{*}{ Mean } & \multirow{2}{*}{ Std. Error } & \multicolumn{2}{|c|}{ 95\% Confidence Interval } \\
\cline { 4 - 6 } & & & Lower Bound & Upper Bound \\
\hline \multirow{2}{*}{ Peer Tutoring } & Male & 23.000 & 2.996 & 16.816 & 29.184 \\
\cline { 2 - 6 } & Female & 24.667 & .999 & 22.605 & 26.728 \\
\hline \multirow{2}{*}{ Storytelling } & Male & 29.500 & 1.223 & 26.975 & 32.025 \\
\cline { 2 - 6 } & Female & 29.250 & 1.498 & 26.158 & 32.342 \\
\hline \multirow{2}{*}{ Control } & Male & 16.000 & 1.340 & 13.235 & 18.765 \\
\cline { 2 - 6 } & Female & 16.400 & 1.340 & 13.635 & 19.165 \\
\hline
\end{tabular}

Table 2 shows that participants in the storytelling group obtained the highest mean score $(\bar{x}=29.375)$, followed by participants in the peer tutoring group (mean score $\bar{x}$ $=23.833)$, while control had the lowest mean score $(\bar{x}=$ 16.200). This shows that participants in the storytelling group had better social skills than those in the peer tutoring and control groups.

$\mathbf{H}_{2}$ : There will be no significant main effect of gender on social skills of pupils with mild intellectual disability in Ibadan, Oyo State

The results presented in Table 1 show that there was a significant main effect of gender on social skills of pupils with mild intellectual disability in Ibadan, Oyo State $\left(F_{(1,29) ;}=45.191, p<.05, \eta^{2}=.218\right)$. This implies that gender contributed significantly to the variation in participants' scores. The eta-value of .218 shows that gender contributed about $22 \%$ to social skills of the participants. Therefore, the null hypothesis was rejected.

Table 3 showed that female participants obtained a higher mean score ( $\bar{x}=23.439$ ), while male participants had a lower mean score $(\bar{x}=22.833)$. This shows that female participants had better social skills than the male group.

Ho 3: There will be no significant interaction effect of treatment and gender on social skills of pupils with mild intellectual disability in Ibadan, Oyo State

The results presented in Table $4.3 \mathrm{a}$ show a significant interaction effect of treatment and gender on social skills of pupils with mild intellectual disability in Ibadan, Oyo State $(F(2,28) ;=49.135, p<.05, \eta 2=.311)$. This implies that the interaction of treatment and gender contributed significantly to the variation in participants' scores. The eta-value of .311 shows that the interaction of treatment and gender contributed about $32 \%$ to social skills of the participants. Therefore, the null hypothesis was not accepted.

Table 4 shows that female participants in the peer tutoring group had a higher mean score $(\bar{x}=24.667)$, while male participant in the same group had a lower mean score $(\bar{x}=23.00)$. In the storytelling group, male participants obtained a higher mean score $(\bar{x}=29.50)$, while female participants in the same group had a lower mean score $(\bar{x}=29.25)$. In the control group, female participants had a higher mean score $(\bar{x}=16.40)$, while male participants in the same group had a lower mean score $(\bar{x}=16.00)$. This shows that male participants in the storytelling group had the best social skills when compared to those in the peer tutoring and control groups.

\section{Discussion of Findings}

This study determined the effect of storytelling, peer tutoring and gender differences on social skills of pupils with mild intellectual disability in Ibadan, Oyo State. 


\section{Main Effect of Treatment on Social Skills of Pupils with Mild Intellectual Disability}

The findings of this study, based on $\mathrm{H}_{1}$, showed a significant main effect of treatment (storytelling and peer tutoring) on social skills of pupils with mild intellectual disability. This finding agreed with those of researchers who observed that peer tutoring affected students' performance $[65,66]$.The findings are aligned with those of Gebes [15], who concluded that peer tutoring was effectively employed in anger management training programmes among high school students. It is also in agreement with the assertion of Yelpaze [17], that peer-mediated social skills training programmes reduced aggression levels of secondary school students. According to the findings, peer tutoring is effective in changing the learning environment from one in which knowledge is transferred to one in which knowledge is approached from multiple and missing perspectives, allowing pupils to learn from one another. Peer tutoring is invariably based on a process of mutual assistance among classmates, which facilitates the transfer of control to the pupils in the classroom.

Moreover, storytelling has proven to be an effective strategy in developing the social skills of pupils with mild intellectual disability. In this regard, significant improvement was recorded in the ability to accept responsibility and sense of control of tutors [23]. The effectiveness of storytelling may be due to the strategy of keeping the learners relaxed and their minds focused on the new skills they are about to learn. In the same vein, storytelling has a significant main effect on the social skills of pupils with mild intellectual disability as studies show the effective use of social stories in teaching safety and social skills [30, 32], for individuals with learning disability [33], behavioral problems [34], and intellectual disability [35].

\section{Main Effect of Gender on the Social Skills of Pupils with Mild Intellectual Disability}

The results showed a significant main effect of gender on social skills of pupils with mild intellectual disability. The null hypothesis was therefore rejected. The finding was largely consistent with our hypotheses and with the work of other investigators $[32,67,68,69]$. The implication of this finding is that on completion of the treatment package, female participants had better social skills than males. These differences were expected for the Nigerian context since studies show that girls are more likely to possess higher social skills and academic competence, while boys often exhibit more problem behaviours [45, 46, 49, 50]. Females outperformed male students in terms of positive behaviour on average. Gender differences in social skills among pupils with mild intellectual disability reflect societal gender expectations. Cultural stereotypes and reactions, according to Deaux
[70], learn, guide, and transmit appropriate sex-roles and sex-typed behaviours. The stereotyping of behaviour will likely prevent boys with mild intellectual disability from developing the same level of social skills as girls.

\section{Interaction Effect of Treatment and Gender on Social Skills of Pupils with Mild Intellectual Disability}

The results indicate a significant interaction of treatment and gender on social skills of pupils with mild intellectual disability, proving the effectiveness of this strategy. This aligns with the submission of Gebes [15] who concluded that peer tutoring employed in anger management training program was effective anger management among students in high school. Philip and Council [65] and Romano and Walker [65] who observed that peer tutoring affects students' performance. The findings align previous studies that social stories were effectively used in teaching safety skills, as well as social skills [30, 32], behavioral problems [34], and pupils with intellectual disability [35]. Previous findings show that boys were more likely than girls to engage in problem behaviors, but girls were more likely to have superior social and academic skills [45, 49, 50]. This is in agreement with the present findings because treatment (peer tutoring and storytelling) and gender significantly enhanced the social skills of pupils with intellectual disability.

\section{Conclusions}

This study was aimed at determining the effect of storytelling and peer tutoring on the social skills of pupils with mild intellectual disability. The two approaches were found to have significant main effects on the social skills of the participants. Teachers were encouraged to be equipped with the necessary and important information regarding diverse teaching methods. In addition, they were implored to be committed to the teaching of the children with mild intellectual disability by using captivating, and interactive techniques appropriate for the learning styles of the learners, especially as related to social skills that could help improve their communication skills.

\section{Recommendations}

Stakeholders should encourage the use of the two strategies (peer tutoring and storytelling) for the development of social skills among pupils with mild intellectual disability. This is because both strategies increase the number of participants required for active interaction and learning with members of the community. In this manner, learning becomes concrete, auditory, and visual. Teachers should think about using social stories to 
encourage pupils' active participation in learning tasks because they had a greater social impact on the social skills of pupils with mild intellectual disabilities. Based on the findings, stakeholders such as teachers, caregivers, and parents of pupils with mild intellectual disabilities should be educated on the benefits of using peer tutoring and storytelling to enhance social skills of pupils with intellectual disability.

\section{Limitation and Suggestion}

The researchers did not find any studies investigating the relationship between the independent variables (peer tutoring, storytelling, and gender) and social skills among pupils with mild intellectual disability. This study was only interested in the effect of two intervention and one moderating variable (gender) as it enhanced social skills. Another limitation was the number of respondents selected for the study. The reason for the small sample size was due to the unique characteristics of adolescents with mild intellectual disability, which made it difficult for their parents to show interests in enrolling them in school.

\section{Funding}

This work was supported by the South African Research Chairs Initiative of the Department of Science and Innovation and National Research Foundation of South Africa. South African Research Chair: Education and Care in Childhood: Faculty of Education: University of Johannesburg South Africa [grant number: 87300, 2017].

\section{REFERENCES}

[1] Westwood, P. "Commonsense methods for children with special needs strategies for the regular classroom." Routledge. 1993

[2] Hetzroni, O. E., Banin, I., "The effect of educational software, video modelling and group discussion on social skill acquisition among students with mild intellectual disabilities." Journal of Applied Research in Intellectual $\begin{array}{lll}\text { Disabilities, } & 30(4), & 757-773 .\end{array}$ https://doi.org/10.1111/jar.12271

[3] Cartledge, G., Milburn, J.F. "Social skill assessment and teaching in the schools". In T. R. Kratochwill (Ed.), Advances in school psychology: Volume III (pp. 175-235). Lawrence Erlbaum Associates. 1983

[4] Avcioğlu, H. "Etkinliklerle sosyal beceri öğretimi [Social skills teaching with activities].” Kök Yayıncılık. 2005

[5] Sergin, C., Giverts, M., "Methods of social skills training and developments." In J. O. Grene B. R. Burleson (Eds.),
Handbook of communication and social interaction skills (pp. 135-178). Lawrence Erlbaum Associates. 2003

[6] Wilson, S. R. Sabee, C. M. "Explicating communicative competence as a theoretical term." In J. O. Greene, B. R. Burleson, Handbook of communication and social interaction skills (pp. 3-50). Mahwah, NJ: Lawrence Erlbaum 2003

[7] Karakuş, T. F., "Ergenlerde algılanan duygusal istismar ile sosyal beceri arasındaki ilişki [The relationship between perceived emotional abuse and social skills in adolescents]." (Unpublished master's thesis), Marmara University, Institute of Educational Sciences, Istanbul. 2006

[8] Carter, A. S., Briggs-Gowan, M. J., Davis, N. O. "Assessment of young children's social-emotional development and psychopathology: Recent advances and recommendations for practice." Journal of Child Psychology and Psychiatry, 45(1), 109-134. 2004 https://doi.org/10.1046/j.0021-9630.2003.00316.x

[9] Kilic, M. K., Gungor Aytar F. A., "The effect of social skills in early childhood, the relationship between social skills and temperament." Education and Science, 42(191) 185-204. 2017 http://dx.doi.org/10.15390/EB.2017.7162

[10] Vygotsky, L.S., “Mind in society.” Harvard University Press. 1978

[11] Piaget, J., "The Mechanisms of Perception.” Basic Books. 1969

[12] Brown, J. S., Collins, A., Duguid, P. "Situated cognition and the culture of learning." Educational Researcher, 18(1), 32-42. (1989, January/February). https://doi.org/10.3102/0 013189X018001032

[13] Austin, J., "The effects of peer tutoring on fifth-grade students' motivation and learning in mathematics." (Master's thesis). The College at Brockport. 2008 https://core.ac.uk/download/pdf/233570664.pdf

[14] Eisenkopf, G., Peer effects, motivation, and learning. Economics of Education Review, 29(3), 364-374. 2010 https://doi.org/10.1016/j.econedurev.2009.08.005

[15] Gebes, H., "The effect of peer supported anger management training program on anger management skills of high school students." (Unpublished master's thesis). Çukurova University, Social Sciences Institute. 2011

[16] Gordon, E. E., 5 ways to improve tutoring programs. Phi Delta Kappan, 90(6), 440-445. 2009 https://doi.org/10.1177/003172170909000614

[17] Yelpaze, İ., "The effectiveness of social skills training program told via peer tutoring on the level of aggression of secondary school students." (Unpublished master's thesis). Gaziantep University, Social Sciences Institute. 2012

[18] Bowman-Perrott, L., Davis, H., Vannest, K., Williams, L., Greenwood, C., Parker, R. "Academic benefits of peer tutoring: A meta-analytic review of single-case research". School Psychology Review, 42(1), 39-55. 2013 https://doi.org/10.1080/02796015.2013.12087490

[19] Bombardelli, O. "Effective teaching practice: Peer tutoring in education for active citizenship. " In Z Bekorogullari, M. Y. Minas, R. X. Thambusamy (Eds) European Proceedings of Social and Behavioural Sciences EpSBS, eISSNm (pp. 
343-355). 2016 https://doi.org/10.15405/epsbs.2016.11.36

[20] Watcyn-Jones, P., Howard-Williams, D. "Pair work 3." Penguin Books. 2002

[21] Scruggs, T. E., Mastropieri, M. A., Marshak, L, "Peer-mediated instruction in inclusive secondary social studies learning: Direct and indirect learning effects". Learning Disabilities Research and Practice, 27(1), 12-20. 2012 https://doi.org/10.1111/j.1540-5826.2011.00346.x

[22] Madrid, L. D., Canas, M., Ortega-Medina, M., "Effects of team competition versus team cooperation in classwide peer tutoring." The Journal of Educational Research, 100(3); 155-160 2007 https://doi.org/10.3200/JOER.100.3.155-160

[23] Mitchem, K. J., Young, K. R., West, R. P., Benyo, J., CWPASM: A classwide peer-assisted self-management program for general education classrooms. Education and Treatment of Children, 24(2), 111-140. 2001

[24] Yardım, H. G. "Matematik derslerinde akran eğitimi yaklaşımının 9. Sınıf ögrencilerine etkisi üzerine eylem araştırması [9th grade of the peer education approach in mathematics lessonsaction research on the impact on students]" (Unpublished master's thesis). Gazi Üniversitesi, Ankara. 2009.

[25] Demirci, N., Çirkinoğlu, A. G., "The effect of peer instruction method to university students' electrostatics achievement and attitudes towards this method." E-Journal of New World Sci. Acad. Educ. Sci. 4(1):240-256. 2009

[26] Savaş, E., "Effect of the science process skills laboratory approach supported with peer-instruction on some of science process skills of pre-service teachers." (Unpublished master's thesis). Balikesir University, Institute of Science and Technology. 2012

[27] Tokgöz, S. "The effect of peer instruction on sixth grade students' science achievement and attitudes." (Unpublished doctoral dissertation). Middle East Technical University, Institute of Science and Technology. 2007

[28] Gray, C. A. (1998). "Social stories and comic strip conversations with students with Asperger syndrome and high-functioning autism.” In E. Schopler, G. B. Mesibov, L. J. Kunce (Eds.), Current issues in autism. Asperger syndrome or high-functioning autism? (pp. 167-198). Plenum Press. https://doi.org/10.1007/978-1-4615-5369-4_ 9

[29] Scattone, D., "Increasing appropriate social interactions of children with autistic spectrum disorders using social stories." (Doctoral dissertation). University of Southern Mississippi. 2002 https://aquila.usm.edu/theses_dissertatio ns/2474

[30] Değirmenci, D. H. "Effect of peer delivered social stories on the crossing skills of primary school students with developmental disabilities" (Unpublished doctoral dissertation). Anadolu University. 2018

[31] Kutlu, M., Comparing the presentation of the social stories with the video model in the teaching of autism prevention skills to individuals with autism. (Unpublished doctoral dissertation).Anadolu University Library. 2016

[32] Süzer, T., "Otizm spektrum bozukluğu olan bireylere cinsel istismardan korunma becerilerinin öğretiminde sosyal öykü yönteminin etkililiği [The effectiveness of the social story method in teaching individuals with autism spectrum disorders to avoid sexual abuse skills]." Anadolu Üniversitesi. 2015

[33] Kalyva, E., Agaliotis, I., Can social stories enhance the interpersonal conflict resolution skills of children with LD? Research in Developmental Disabilities, 30(1), 192-202. 2009 https://doi.org/10.1016/j.ridd.2008.02.005

[34] Toplis, R., Hadwin, J. A., "Using social stories to change problematic lunchtime behaviour in school." Educational Psychology in Practice, 22(1), 53-67. 2006) https://doi.org/10.1080/02667360500512437

[35] Olçay-Gül, S., Tekin-İftar, E., "Family generated and delivered social story intervention: Acquisition, maintenance, and generalization of social skills in youths with ASD." Education and Training in Autism and Developmental Disabilities, 51(1), 67-78. 2016

[36] Aksoy, P. "Hikâye anlatma temelli ve oyun temelli sosyal beceri eğitiminin anasınıfina devam eden çocukların sosyal becerilerine etkisinin incelenmesi [Investigation of the effect of storytelling and game-based social skills training on the social skills of children attending kindergarten]." (Unpublished doctoral dissertation). Ankara University. 2014

[37] Aksoy, P. "Hikâye anlatma temelli ve oyun temelli sosyal beceri eğitiminin anasınıfina devam eden çocukların sosyal becerilerine etkisinin incelenmesi [Investigation of the effect of storytelling and game-based social skills training on the social skills of children attending kindergarten]." (Unpublished doctoral dissertation). Ankara University. 2014

[38] Fetko, E. E., Collins, B. C., Hager, K. D., Spriggs, A. D., "Embedding science facts in leisure skill instruction conducted by peer tutors." Education and Training in Autism and Developmental Disabilities, 48(3), 400-411. 2013

[39] Tekin-İftar, E. "Effectiveness of peer delivered simultaneous prompting on teaching community signs to students with developmental disabilities." Education and Training in Developmental Disabilities, 38(1), 77-94. 2003

[40] Godsey, J. R., Schuster, J. W., Lingo, A. S., Collins, B. C., Kleinert, H. L., "Peer-implemented time delay procedures on the acquisition of chained tasks by students with moderate and severe disabilities." Education and Training in Developmental Disabilities, 43(1), 111-122. 2008

[41] Wolery, M., Werts, M. G., Snyder, E. D., Caldwell, N. K., "Efficacy of constant time delay implemented by peer tutors in general education classrooms. Journal of Behavioral $\begin{array}{llll}\text { Education, } & 4(4), & 415-436 . & 1994 .\end{array}$ https://doi.org/10.1007/BF01539542

[42] Jameson, J. M., McDonnell, J., Polychronis, S., Riesen, T., "Embedded, constant time delay instruction by peers without disabilities in general education classrooms." Intellectual and Developmental Disabilities, 46(5), 346-363. $2008 \mathrm{https}: / /$ doi.org/10.1352/2008.46:346-363

[43] Bishop, A. R., Christensen-Sandfort, R. J. "The impact of peer-implemented milieu teaching on the communication skills of young children with autism spectrum disorder." Poster presented at the ABAI 38 Annual Convention, Seattle, Washington, USA. 2012 
[44] Sams, L. A., "It is time to play! Peer implemented pivotal response training with a child with autism during recess." (Master's thesis, University of South Florida.) 2009 Retrieved from http://scholarcommons.usf.edu/etd/2

[45] Keane, S. P., Calkins, S. D., "Predicting kindergarten peer social status from toddler and preschool problem behavior." Journal of Abnormal Child Psychology, 32(4), 409-423. 2004https://doi.org/10.1023/B:JACP.0000030294.11443.4

[46] Qi, C. H., Kaiser, A. P., "Behavior problems of preschool children from low-income families: Review of the literature." Topics in Early Childhood Special Education, 23(4), 188-216. 2003 https://doi.org/10.1177/02711214030 230040201

[47] Roberts, W., Strayer, J., "Empathy, emotional expressiveness, and prosocial behavior." Child Development, 67(2), 449-470. 1996 https://doi.org/10.230 $7 / 1131826$

[48] Nemeth, E., "Gender differences in reaction to public achievement feedback." Educational Studies, 25(3), 297 310. 1999 https://doi.org/10.1080/03055699997819

[49] Taylor, C. A., Liang, B., Tracy, A. J., Williams, L. M., Seigle, P., "Gender differences in middle school adjustment, physical fighting, and social skills: evaluation of a social competency program." The Journal of Primary Prevention, 23(2), 259-272. 2002 https://doi.org/10.1023/A:101997661 7776

[50] Margetts, K., "Children's adjustment to the first year of schooling: Indicators of hyperactivity, internalizing and externalizing behaviors." International Journal of Transitions in Childhood, 1, 36-44. 2005 https://www.researchgate.net/publication/229039153_Chil dren\%27s_adjustment_to_the_first_year_of_schooling_In dicators_of_hyperactivity_internalizing_and_externalizing behaviors

[51] Nourani, Kh. "Social skills and adaptive behavior of Iranian preschoolers: Teachers' and parents' ratings." (Unpublished doctoral thesis). Department of human development and applied psychology; Ontario institute for studies in education of the University of Toronto 1998

[52] Berglund, E., Eriksson, M., Westerlund, M. "Communicative skills in relation to gender, birth order, childcare and socioeconomic status in 18-month-old children." Scandinavian Journal of Psychology, 46, 485491. 2005

[53] Feldman, R. S., "Cognitive development. Chapter 5 Cognitive Development in Infancy. Fifth edition.” Pearson Prentice Hall. Upper Saddle River, NJ. pp. 171-181. 2009

[54] Mildner, V. (2008). "The cognitive neuroscience of human communication." Lawrence Erlbaum Associates

[55] Kret, M. E.; De Gelder, B., "A review on sex differences in processing emotional signals." Neuropsychologia, 50(7), 1211-1221. 2012. https://doi.org/10.1016/j.neuropsycholo gia.2011.12.022

[56] Śmieja, M., Orzechowski, J., Stolarski, M. S., "TIE: An Ability Test of Emotional Intelligence". PLOS ONE, 9(7), e103484. 2014 https://doi.org/10.1371/journal.pone.01034 84
[57] Thompson, A. E., Voyer, D., "Sex differences in the ability to recognise non-verbal displays of emotion: A meta-analysis," Cognition and Emotion, 28(7), 1164-1195. 2014 https://doi.org/10.1080/02699931.2013.875889

[58] Miller, J. L., Macedonia, C., Sonies, B. C., "Sex differences in prenatal oral-motor function and development." Developmental Medicine Child Neurology, 48(6), 465-470. 2006 https://doi.org/10.1017/S0012162206001009

[59] Cassidy, J. W., Ditty, K. M., "Gender differences among newborns on a transient otoacoustic emissions test for hearing." Journal of Music Therapy, 38(1), 28-35. 2001 https://doi.org/10.1093/jmt/38.1.28

[60] Erickson, K., Schulkin, J., "Facial expressions of emotion: A cognitive neuroscience perspective". Brain and Cognition, 52(1), 52-60. 2003 https://doi.org/10.1016/S0278-2626(03)00008-3

[61] Guinsburg, R., De Araújo Peres, C., Branco de Almeida, M. F., De Cássia Xavier Balda, R., Cássia Berenguel, R., Tonelotto, J., Kopelman, B. I., "Differences in pain expression between male and female newborn infant"s. Pain, 85(1-2), 127-133. 2000 https://doi.org/10.1016/s030 4-3959(99)00258-4

[62] Gunnar, M. R., Donahue, M., "Sex differences in social responsiveness between six months and twelve months." Child Development, 51, 262-265. 1980

[63] Oyefeso E. O. "Two instructional strategies, basic science performance and functional Independence of pupils with Mild Intellectual disability in Ibadan, Oyo state". (Unpublished PhD Thesis). University of Ibadan, Nigeria 2018

[64] Gajewski, N., Him, P., Mayo, P., "Social skill strategies: A social-emotional curriculum for adolescents". Thinking Publications. 1998

[65] Philip, L. Council, B., "Peer tutoring: Student achievement, confidence and the teacher's role" (Unpublished master's thesis). University of Nebraska-Lincoln, NE. 2010

[66] Romano, P., Walker, J., "Bio buddies:" Peer tutoring as an instructional strategy". NERA Conference Proceedings 2010. 2010 Retrieved from http://digitalcommons.uconn.e du/nera_2010/3/

[67] Campbell, S. B. "Longitudinal studies of active and aggressive preschoolers: Individual differences in early behavior and outcomes". In D. Cicchetti S. L. Toth (Eds.), Internalizing and externalizing expressions of dysfunction, Rochester Symposium on Developmental Psychopathology (pp. 57-89). Erlbaum. 1991

[68] Campbell, S. B. "Behavior problems in preschool children: Clinical and developmental issues" (2nd ed.). Guilford Press 2002

[69] Margetts, K. “Children's adjustment to the first year of schooling: Indicators of hyperactivity, internalizing and externalizing behaviors." Summary of a paper presented at the Australian Association for Research in Education, 4-7 December, Sydney, Australia. (2000, December 4-7). https://www.aare.edu.au/data/publications/2000/mar00540. pdf

[70] Deaux, K. "Defining gender roles and stereotypes 
psychological constructions of masculinity and femininity." In D. L. R Anselmi, A. L. Law (Eds.), Questions of gender:
Perspectives and paradoxes (pp. 206-215). McGraw Hill. 1998 